\title{
Risk factors in the development of breast cancer among Indonesian women
}

Joedo Prihartono*, Yoshiyuki Ohno ${ }^{\dagger}$, Setiawati Budiningsih*, Drupadi S Dillon", Gunawan Tjahjadi ${ }^{\S}$, Esti Soetrisno», Endang Hardjolukito§, Didid Tjindarbumi`, Muchlis Ramli॰, Idral Darwis`, Goi Sakamoto?, Sadao Suzuki ${ }^{\dagger}$, Kenji Wakai ${ }^{\dagger}$, Santoso Cornain ${ }^{\S}$

\begin{abstract}
Abstrak
Telah dilaksanakan suatu penelitian kasus-kontrol dengan 300 triplet untuk mengidentifikasi faktor risiko terjadinya kanker payudara di kalangan wanita Indonesia. Dari dua belas faktor risiko yang di analisa secara univariate terdapat enam faktor yang secara bermakna berkaitan dengan kejadian kanker payudara. Analisa lebih lanjut dengan pendekatan regresi logistik menunjukkan bahwa adanya lima faktor risiko yang mempunyai pengaruh nyata dalam pertumbuh kanker payudara, yakni keterlambatan menars (OR 2,35 CI 1,60-3,44), laktasi jangka pendek (OR 2,21 CI 1,02-4,78), trauma payudara (OR 1,98 CI 1,12-3,49), konsumsi lemak berlebihan (OR 1,81 CI 1,30-2,52), dan menopause (OR I,54 CI 1,15-2,05).
\end{abstract}

Abstract

A case-control study to identify risk factors on the development of breast cancer among Indonesian women has been conducted using 300 triplets. Twelve potential determinant factors have been assessed using uni-variant analysis, and six of them showed significant association with breast cancer. Further analysis using logistic regression method revealed that five factors, namely late menarche $O R=$ 2.35 (1.60-3.44), short lactation $O R=2.21(1.02-4.78)$, breast trauma $O R=1.98(1.12-3.49)$, excessive fat consumption $O R=1.81$ (1.30-2.52), and menopause $O R=1.54(1.15-2.05)$ have real effect on the development of breast cancer.

Keywords: Case-control study, risk factor, breast cancer, epidemiology.

\section{INTRODUCTION}

In Indonesia, intensive public health program in controlling acute communicable diseases and nutritional problems has lead to significant improvement of health condition. Incidence rates of many major communicable diseases have decreased, and life expectancy has increased. On the other hand, chronic diseases such as cardio-vascular and malignancies started to show significant impact on the ten leading causes of death. 1 - 4 Breast cancer ranked the second among Indonesian females; with slightly increasing trend of its specific incidence rate observed within 5 years pathology based cancer registry from 1988 up to 1992.5

* Department of Community Medicine, Faculty of Medicine, University of Indonesia, Jakarta 10320, Indonesia

+ Department of Preventive Medicine, School of Medicine, Nagoya University, Nagoya 466, Japan

\# Department of Nutrition, Faculty of Medicine, University of Indonesia, Jakarla 10430, Indonesia

\& Department of Pathology, Faculty of Medicine, University of Indonesia, Jakarta 10430, Indonesia

- Department of Surgery, Faculty of Medicine, University of Indonesia, Jakarta 10430, Indonesia

I Department of Pathology, Cancer Institute Hospital, Tokyo 170, Japan
Malignancy creates the most severe psychological impact to the family members compared to other chronic diseases. Breast cancer is the second highest of malignancy among the Indonesian women just after the cervical cancer. The majority of diagnosed and treated cases in the General Hospital came in late stages, thus lowering the five-year survival rate. ${ }^{6}$ Intensive public education program must be developed using a multi disciplinary approach.

There are many factors, which have been studied in the developed countries as having significant role on the development of breast cancer. High consumption of fatty food, hormonal use, breast trauma, menopause, and genetic traits showed causal relationship with breast cancer among women in the affluent countries. ${ }^{7-24}$ On the other hand the practice of longterm lactation can reduce the risk of breast cancer. ${ }^{25-}$ 33 The Indonesian local diet tends to content excessive saturated fatty acids, both animal and vegetable sources. 38 With the difference on environmental conditions and the way of life, there is a need to confirm whether these risk factors also played important role among Indonesian women. This study was intended to identify significant risk factors on the development of breast cancer in Indonesia and assessed their rank of influence. 


\section{MATERIALS AND METHODS}

A case-control study design with 1:2 ratio was applied in this assessment. Two types of study subjects were used in this study. The patients were defined as all newly diagnosed breast cancer patients who came to Jakarta General Hospital during the study period of 1989 to 1992. Almost all of breast cancer patients in the area, especially those from middle to lower socio economic level, will be referred to this hospital. The diagnosis of breast cancer was performed either histopathologically or using Ultra Sound/Mammography. 6,35

The controls were defined as non-breast tumor and non-malignancy patients who came for medical assistance to the surgery or other departments of the General Hospital during the study period. For every breast cancer patient there were two hospital controls at the same age range to increase its statistical power. Using a $95 \%$ confidence limit, statistical power of $80 \%$ and assumed relative risk of two times, with an average $40 \%$ of risk factor's exposure rate, this study has recruited 300 cases and 600 controls in a single hospital.

Demographic characteristics of the respondents were gathered through a structured interview, while medical data were collected through physical examination. Nutritional data were collected and probed indepthly using a simple food model. Since the control must be free from any breast tumor, the trained paramedics also examined the respondents through breast palpation to exclude controls with breast lump.

The twelve risk factors which were included in this study are present weight, age at first sexual contact, parity, education, late menarche, menopause, hormonal use, breast trauma, lactation, genetic trait, fat and protein consumption. Each potential risk factor was assessed through uni-variant analysis and was measured its estimated Relative Risk and the 95\% confidence intervals. For all significant risk factors, a further analysis has been applied to assess the strength of association for each determinant factor given that all other factors retained as constant. Logistic regression method was selected for this multi-variate analysis. 36

Excessive fat and high protein consumption was defined if the subject consumed more than 4 days per week at usual food-size. Low educational level was defined for those who only had elementary education. Late menarche was defined for subject who experi- enced menarche at the age of 16 years or later. Shortterm breast-feeding was defined for subject who has a total breast-fed period of less than 6 months.

\section{RESULTS}

Age distribution of cases and controls showed that the majority of study respondents came from 30 to 49 years age group, $54 \%$ for cases and $53 \%$ for controls. There are small percentages of cases and controls that aged less than 30 years. Old respondents who aged more than 69 years comprised of 3\% for cases and $2.5 \%$ for controls. The average age of cases is $47 \pm$ 11.9 years, while for controls is $46.9 \pm 12$ years (see Table 1).

Table 1. Age distribution of cases and controls

\begin{tabular}{lcc}
\hline Age distribution & Cases $(\mathrm{n}=300)$ & Controls $(\mathrm{n}=600)$ \\
\hline Under 30 years & $4.7 \%$ & $5.0 \%$ \\
$30-39$ years & $23.3 \%$ & $27.8 \%$ \\
$40-49$ years & $31.0 \%$ & $25.8 \%$ \\
$50-59$ years & $18.3 \%$ & $20.8 \%$ \\
$60-69$ years & $19.7 \%$ & $18.0 \%$ \\
Above 69 years & $3.0 \%$ & $2.5 \%$ \\
\hline Mean age and S.D & $47.0 \pm 11.9$ & $46.9 \pm 12.0$ \\
\hline
\end{tabular}

Among the 300 breast cancer cases, $80 \%$ of them came at the late stages. More than $57 \%$ of breast cancer cases are already at the III-B or more severe stage which have low response to the available treatment.

Table 2. Clinical stage of breast cancer cases

\begin{tabular}{lcc}
\hline Clinical stage & Number & Percentage \\
\hline Stage I & 14 & 4.7 \\
Stage II & 46 & 15.3 \\
Stage III-A & 68 & 22.7 \\
Stage III-B & 116 & 38.7 \\
Stage IV & 56 & 18.6 \\
\hline TOTAL & 300 & 100.0 \\
\hline
\end{tabular}

The selection of controls did not interfere with the possible determinant factors. No control subject was diagnosed of having any disease, which has confirmed causal association with any potential factor, whether increasing or decreasing association (see Figure 1). The majority of control group were healthy women who visit the hospital for consultation. Thirty-four percents of control visited surgery department seeking medical assistance for ordinary medical problems. 


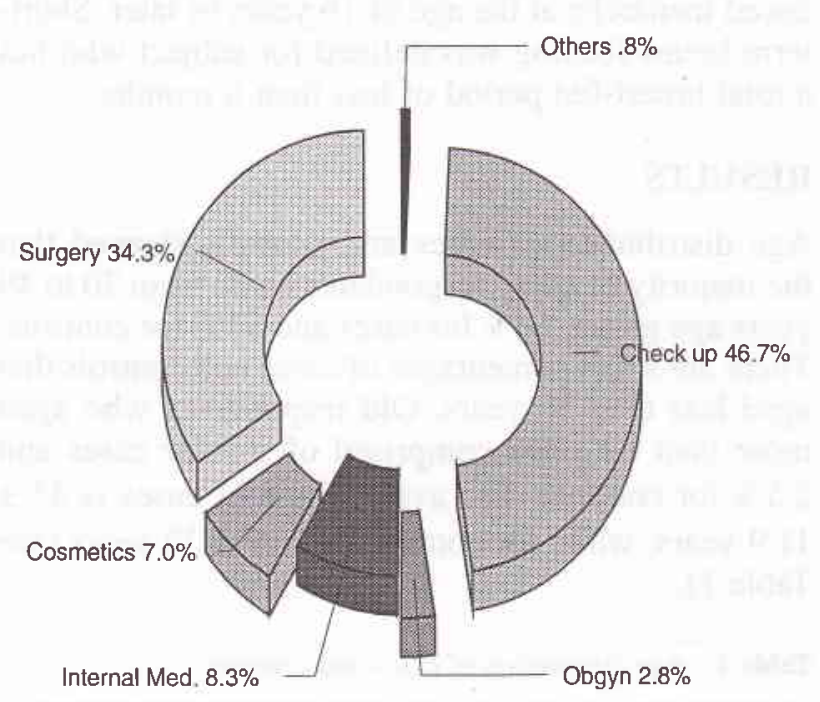

Figure 1. Clinical diagnosis of controls

Uni-variant analysis of determinant factors showed that only six of them have significant role on the development of breast cancer and need further analysis. Table 3 shows that present weight and the age at first sexual contact did not have significant correlation with the development of breast.

Table 3. Body weight and age of sexual activity compared between breast cancer cases and controls

\begin{tabular}{lcrcrc}
\hline \multirow{2}{*}{ Factors } & \multicolumn{2}{c}{ Cases } & \multicolumn{2}{c}{ Controls } & p \\
& Mean & SD & Mean & \multicolumn{1}{c}{ SD } & \\
\hline Weight & 50.5 & 14.2 & 51.0 & 14.2 & 0.569 \\
$1^{\text {st }}$ sexual age & 19.7 & 4.6 & 19.9 & 3.9 & 0.578 \\
\hline
\end{tabular}

Tables 4 and 5 show that educational level and parity status were not significantly linked with breast cancer risk, eventhough low or no education appeared to increase the risk by 1.18 and 1.24 times.

Table 4. Impact of educational level to breast cancer

\begin{tabular}{lrcc}
\hline Education level & Cases & Control & OR \\
\hline Middle education & 114 & 256 & \\
Low education & 108 & 195 & $1.24(0.90-1.72)$ \\
No education & 78 & 149 & $1.18(0.83-1.67)$ \\
\hline Total & 300 & 600 & \\
\hline
\end{tabular}

Table 5. Impact of parity status to breast cancer

\begin{tabular}{|c|c|c|c|}
\hline Parity status & Cases & Control & OR \\
\hline No parity & 43 & 84 & \\
\hline $1-3$ parity & 134 & 256 & $1.02(0.67-1.56)$ \\
\hline $4+$ parity & 123 & 260 & $0.92(0.60-1.41)$ \\
\hline Total & 300 & 600 & \\
\hline
\end{tabular}

Table 6 shows an association between lactation and breast cancer. Those women who never breast-fed only showed a slight increase of risk, but it is not a significant association. On the other hand, those women who breast fed for less than 6 months significantly experienced a 2.6 times risk.

Table 6. Impact of breast-feeding to breast cancer

\begin{tabular}{lrrll}
\hline Breast-feeding & Cases & Control & OR \\
\hline Long period & 231 & 490 & & \\
Short period & 16 & 13 & 2.61 & $(1.27-5.38)$ \\
Never brestfed & 53 & 96 & 1.17 & $(0.80-1.68)$ \\
\hline Total & 300 & 600 & & \\
\hline
\end{tabular}

Table 7 shows that hormonal drug use such as contraceptive methods appeared to affect the development of breast cancer. There was no significant relationship of genetic trait with this kind of malignancy. Late menarche has the second strongest causal relationship with a relative risk of 2.3 times just behind short-term breast-feeding. The experience of physical breast trauma also shows significant impact on the development of breast cancer. Women who already are menopause or those who consumed excessive fatty food and high protein diet show higher risk of developing breast cancer compared to average women.

Table 7. Impact of other factors to breast cancer

\begin{tabular}{lrrrrc}
\hline Factors & \multicolumn{2}{c}{ Cases } & \multicolumn{2}{c}{ Control } & OR \\
& \multicolumn{1}{c}{+} & \multicolumn{1}{c}{+} & - & \\
\hline Late menarche & 67 & 233 & 66 & 534 & $2.33(1.60-3.38)$ \\
Breast trauma & 26 & 274 & 28 & 572 & $1.94(1.12-3.37)$ \\
Menopause & 163 & 137 & 271 & 329 & $1.44(1.09-1.91)$ \\
Hormonal drug & 38 & 262 & 52 & 548 & $1.53(0.98-2.38)$ \\
Genetic trait & 53 & 247 & 92 & 508 & $1.19(0.82-1.72)$ \\
Excessive fat & 97 & 203 & 118 & 482 & $1.95(1.42-2.67)$ \\
High Protein & 193 & 107 & 342 & 258 & $1.36(1.02-1.81)$ \\
\hline
\end{tabular}


When logistic regression analysis method was applied for the six significant risk factors, high protein consumption did not show real impact on breast cancer. By keeping other risk factors constant, the causal relationship of high protein diet diminished. Late menarche, breast trauma, menopause remained as significant as short-term lactation and consumption of excessive fat.

Table 8. Estimated Relative Risk of determinant fa .ors

\begin{tabular}{lcc}
\hline Factors & Uni-variant & Multi-variant \\
\hline Late menarche & $2.33(1.60-3.38)$ & $2.35(1.60-3.44)$ \\
Breast trauma & $1.94(1.12-3.37)$ & $1.98(1.12-3.49)$ \\
Menopause & $1.44(1.09-1.91)$ & $1.54(1.15-2.05)$ \\
Short lactation & $2.61(1.27-5.38)$ & $2.21(1.02-4.78)$ \\
Excessive fat & $1.95(1.42-2.67)$ & $1.81(1.30-2.52)$ \\
High protein & $1.36(1.02-1.81)$ & $1.24(0.91-1.67)$ \\
\hline
\end{tabular}

\section{DISCUSSION}

As one of the most prevalent female malignancies in the world, there were many researches have been conducted on breast cancer. Long list of confirmed determinant factors have been revealed through series of worldwide efforts of researchers. These determinant factors can be classified into two categories, namely precipitating factors and protecting factors. 41- 43

This case control study has been conducted to confirm causal relationship of twelve important determinant factorls with the development of breast cancer among Indonesian women. Unlike women in the developed countries, the Indonesian women tend to differ in many aspects such as genetically, physically, culturally, and socio economically. 42 - 48 These differences have affected also the way of known determinant factors in influencing the development of breast cancer.

Uni-variant statistical analysis showed that body weight and age at the first sexual contact do not have any impact on the development of breast cancer among Indonesian women. The average body weight among the Indonesian women tends to be much less compared to women in the developed countries. 45,46 Obesity, which is related to excessive fat accumulation, has not been found to be significant factor in this study.

The education level, parity status, hormonal drug use and genetic trait did not show any effect on the de- velopment of breast cancer among Indonesian women. Calculation of Odds Ratio and its $95 \%$ confidence interval showed that these variables need not to be pursued further in a multi-variant analysis. Unlike previous allegation, the use of hormonal drugs such as contraceptive methods did not affect this malignancy. Other variables such as excessive fat or protein consumption, menopause status, late menarche, short-term lactation, and breast trauma gave Odds Ratio which significantly higher than one and need to be included in the logistic regression analysis.

Excessive fat consumption, menopause, late menarche, short-term lactation, and breast physical trauma show constant high risk of developing breast cancer. The level of Odds Ratio of these constant factors did not differ significantly after multi-variant analysis. On the other hand, excessive protein consumption diminishes its influence after being controlled by other determinant factors. This finding showed that actually protein consumption does not affect the development of breast cancer, but it tend to blend with high fat consumption.

Many previous studies gave strong evidences of long-term breast-feeding as protecting factor of breast cancer. ${ }^{25-33}$ In this study, long-term lactation of more than 6 months did not show enough significant reduction of risk. On the other hand, short-term lactation has raised the risk significantly compared to those who breast-fed longer. The theory of premature braking of endogenous hormonal factors was assumed to have effect in this situation. Once the baby has sucked the papillae and induced active production of hormonal, the process can not be reversed drastically. The mammary gland cells that have been forced to produce milk by this hormone, needs time in adjusting themselves when the mother start to wean the baby. If this induction was stopped abruptly, the endogenous impact is very great and creates the uncontrolled proliferation of mammary gland cells.

In short, this study revealed the following major findings. a) The majority of hospitalized breast cancer cases in Indonesia were on the late stages, b) The study has identified precipitating risk factors such as late menarche, breast trauma, excessive fat consumption, and menopause, c) The early weaning process tend to precipitate breast cancer development.

\section{Acknowledgments}

The authors like to thank to the nurses, Ms. Ros and Emi, and public health nurses, Ms. July and Ms. Er- 
laini for excellent epidemiological data collection. We are also indebted to SDP staffs for helping in data processing. This work was supported by the Ministry of Education, Science, Sports and Culture of Japanese Government, Grants No. 01042007, 04042013 and 06042006; and was partially supported by the Indonesian Cancer Foundation. This collaborative study was a part of Special Cancer Research project in Monbusho International Scientific Research Program, with the approval of the Dean, Faculty of Medicine, University of Indonesia, No. 4383/PT02.H4. $\mathrm{FK} / \mathrm{E} / 88$

\section{REFERENCES}

1. Research and Development Center, MOH. Indonesian National House hold Survey 1986. Jakarta, 1987.

2. Demographic Study Center, NFPCB. Indonesian Demographic and Health Survey 1991. Jakarta, 1992.

3. Research and Development Center, MOH. Indonesian National House hold Survey 1992. Jakarta, 1993.

4. Demographic Study Center, NFPCB. Indonesian Demographic and Health Survey 1994. Jakarta, 1995.

5. Cornain S, Mangunkusumo R, Prihartono J, Nasar IM. Ten most frequent cancer in Indonesia: Pathological based cancer registry data of 1988-1992. In: Cancer Registry in Indonesia. National Cancer Registry Center, Jkt Coordinating Board, 1997.

6. Tjindarbumi D. Management and Results of Operable Breast Cancer in several Hospitals in Jakarta: A 10 year Survival Rate Observation. Indon J Oncol 1991; 2: 147-60.

7. Brownson RC, Blackwell CW, Pearson DK, Reynolds RD, Richens JW, Papermaster BW. Risk of Breast Cancer in Relation to Cigarette Smoking. Arch Intern Med, 1988; 148: 140-4.

8. Chu SY, Lee NC, Wingo PA, Webster LA. Alcohol Consumption and the Risk of Breast Cancer. Am J Epidemiol. 1989, $130: 867-77$

9. Chu SY, Stroup NE, Wingo PA, Lee NC, Peterson HB, Gwinn ML, et al. Cigarette Smoking and the Risk of Breast Cancer. Am J Epidemiol, 1990; 131: 244-53.

10. Ferraroni M, Decarli A, Willet WC, Marubini E. Alcohol and Breast Cancer Risk: A Case-control Study from Northern Italy. Int J Epidemiol, 1991; 20: 859-64.

11. Field NA, Baptiste MS, Nasca PC, Metzger BB. Cigarette Smoking and Breast Cancer. Int J Epidemiol, 1992; 21: 8428.

12. Gapstur SM, Potter JD, Sellers TA, Folsom AR. Increased Risk of Breast Cancer With Alcohol Consumption in PostMenopausal Women. Am J Epidemiol, 1992; 136: 1221-31.

13. Howe G, Rohan T, Decarli A, Iscovich J, Kaldor J, Katsouyanni $\mathrm{K}$, et al. The Association Between Alcohol and Breast Cancer Risk: Evidence from the Combined Analysis of six Dietary Case-control Studies. Int J Cancer, 1991; 47: 707-10.
14. Kato I, Torminaga S, Terao C. Alcohol Consumption and Cancers of Hormone-Related Organs in Females. Jpn J Clin Oncol, 1989; 19: 202-7.

15. London SJ, Colditz GA, Stampfer MJ, Willet WC, Rosner BA, Speizer FE. Prospective Study of Smoking and the Risk of Breast Cancer. J Natl Cancer Inst, 1989; 81: 1625-31.

16. Meara J, McPherson K, Roberts M, Jones L, Vessey M. Alcohol, Cigarette Smoking and Breast Cancer. Br J Cancer, 1989; 60: 70-3.

17. Nasca PC, Baptiste MS, Field NA, Metzger BB, Black M, Kwon S, et al. An Epidemiological Case-control Study of Breast Cancer and Alcohol Consumption. Int J Epidemiol, 1990; 19: 532-8.

18. Segala C, Gerber M, Richardson S. The Pattern of Risk Factors for Breast Cancer in a Southern France Population: Interest for a Stratified Analysis by Age at Diagnosis. $\mathrm{Br} \mathrm{J}$ Cancer, 1991; 64: 919-25.

19. Simon MS, Carman W, Wolfe R, Schottenfeld D. Alcohol Consumption and the Risk of Breast Cancer: A Report from the Tecumeh Community Health Study. J Clin Epidemiol, 1991; 44: 755-61.

20. Richardson S, de Vincenzi I, Pujol H, Gerber M. Alcohol Consumption in a Case-control Study of Breast Cancer in Southern France. Int J Cancer, 1989; 44: 84-9.

21. Rohan TE, Baron JA. Cigarette Smoking and Breast Cancer. Am J Epidemiol, 1989; 129: 36-42.

22. Rosenberg L, Palmer JR, Miller DR, Clarke EA, Shapiro S. A Case-control Study of Alcoholic Beverage Consumption and Breast Cancer. Am J Epidemiol, 1990; 131: 6-14.

23. Schatzkin A, Carter Cl, Green SB, Kreger BE, Splansky GL, Anderson KM, et al. Is Alcohol Consumption Related to Breast Cancer? Results from the Framingham Heart Study. J Natl Cancer Inst, 1989; 81: 31-5.

24. Schechter MT, Miller AB, Howe GR, Bainer CJ, Craib KJ, Wall C. Cigarette Smoking and Breast Cancer: Case-control Studies of Prevalence and Incidence Cancer in the Canadian National Breast Screening Study. Am J Epidemiol, 1989; 130: $213-20$.

25. Ewertz M, Duffy SW. Risk of Breast Cancer in Relation to Reproductive Factors in Denmark. Br J Cancer, 1988; 58 : 99 . 104.

26. Kato I, Miura S, Kasumi F, Iwase T, Tashiro H, Fujita Y, et al. A Case-control Study of Breast Cancer Among Japanese Women: With Special Reference to Family History and Reproductive and Dietary Factors. Breast Cancer Res Treat, 1992; 24: 51-9.

27. Kvale G, Heuch I. Menstrual Factors and Breast Cancer Risk. Cancer. 1988, 62 : 1625-31.

28. la Vecchia C, Negri E, Franceschi S, Parazizini F. Longterm Impact of Reproductive Factors on Cancer Risk. Int J Cancer, 1993; 53: 215-9.

29. Layde PM, Webster LA, Baughman AL, Wingo PA, Rubin GL, Ory HW. The Independent Associations of Parity, Age at First Fullterm Pregnancy, and Duration of Breast-feeding With the Risk of Breast Cancer. J Clin Epidemiol, 1989; 42: 963-73. 
30. Siskind V, Schofield F, Rice D, Bain C. Breast Cancer and Breast-feeding: Results from an Australian Case-control Study. Am J Epidemiol, 1989; 130: 229-36.

31. Olsson H, Landin-Olsson M, Gullberg B. Retrospective Assessment of Menstrual Cycle Length in Patients With Breast Cancer, in Patients With benign Breast Disease, and in Women Without Breast Disease. J Natl Cancer Inst, 1983; 70: $17-20$.

32. Vatten LJ, Kvinnsland S. Body Height and Risk of Breast Cancer: A Prospective Study of 23,831 Norwegian Women. Br J Cancer, 1990; 61: 881-5.

33. Yoo KY, Tajima K, Kuroishi T, Hirose K, Yoshida M, Miura $S$, et al. Independent Protective Effect of Lactation Against Breast Cancer: A Case-control Study in Japan. Am J Epidemiol, 1992; 135: 726-33.

34. Nutrition Directorate, Minister of Health, Republic of Indonesia. Recommended Dietary Allowances for the Indonesian Women: Manual for Nutritional Program. Jakarta, 1990.

35. World Health Organization. International Classification of Diseases. $10^{\text {th }}$ Revision, Geneve, 1990.

36. SchJesselman JJ. Case Control Studies. Oxford Univ.Press Inc., New York, 1982.

37. Wakai K, Ohno Y, Watanabe S, Sakamoto G, Suzuki S, Kubo F. Risk Factors for Breast Cancer Among Japanese Women in Tokyo: A Case-control Study. J Epidemiol 1994; 4: 65-71.

38. Donn AS, Muir CS. Breast Cancer: Epidemiology and risk factors. In: Khogali M, Omar YT, Gjorgov A, Ismail AS, Editors. Cancer Prevention in Developing Countries. Proceedings of the $2^{\text {nd }}$ UICC Conference on Cancer prevention, $\mathrm{Ku}$ wait, 1986. Oxford: Pergamon Press, 1986: 155-66.
39. Kelsey JL, Horn-Ross PL. Breast Cancer: Magnitude of the problem and descriptive epidemilogy. Epidemiology Reviews, 1993; 15: 7-16.

40. Hsieh CC, Trichopoulos D, Katsouyanni K, Yuasa S. Age at Menarche, Age at Menopause, Height, Weight, and Obesity as Risk Factors for Breast Cancer: Associations and Interactions in an International Case-control Study. Int $\mathbf{J}$ Cancer, 1990; 46: 796-800

41. Tretli S. Height and Weight in Relation to Breast Cancer Morbidity and Mortality: A Prospective Study of 570,000 Women in Norway. Int J Cancer, 1989; 44: 23-30.

42. Yoo KY, Tajima K, Kuroishi T, Hirose K, Miura S, Murai H, et al. Life-style in Relation to the Risk of Breast Cancer. J Epidemiol (Suppl), 1992; 2: 8155-65.

43. Yu SZ, Lu RF, Xu DD, Howe GR. A Case-control Study of Dietary and Non Dietary Risk Factors for Breast Cancer in Shanghai. Cancer Res, 1990; 50: 5017-21.

44. Zaridze D, Lifanova Y, Maximovitch D, Day NE, Duffy SW. Diet, Alcohol Consumption and Reproductive Factors in a Case-control Study of Breast Cancer in Moscow. Int J Càncer, 1991; 48: 493-501.

45. Parazzini F, la Vecchia C, Negri E, Bruzzi P, Palli D, Boyle P, et al. Anthropometric Variables and Risk of Breast Cancer. Int J Cancer, 1990; 45: 397-402.

46. Sellers TA, Kushi LH, Potter JD, Kaye SA, Nelson CL, McGovern PG, et al. Effect of Family History, Body-fat Distribution and Reproductive Factors on the Risk of Postmenopausal Breast Cancer. N Engl J Med, 1992; 326: 13239. 